\title{
SOME PRACTICAL ASPECTS OF THE CHEMICAL TREATMENT OF PASTURES
}

\author{
By L. W. BLACKMORE, Department of Agriculture, Dannevirke
}

\begin{abstract}
SUMMARY
SINCE the original trials with chemicals on browntop (Agrostis tenuis) dominant swards were begun in autumn of 1956 a large number of experiments has been done by officers of the Extension Division. This paper deals only with work done in the Dannevirke Instructorate.
\end{abstract}

RESULTS OF 1956-57 TRIALS

To provide a link between the present trials and those previously described in my paper to the 1957 Conference I will briefly summarise the results of the eight $1956-57$ trials.

\section{Flat Country (4 Trials)}

Two of these trials can be regarded as successful in that the objective, that of destroying the existing pastures with chemicals and establishing entirely new pastures in their places, was achieved. In one of these trials the chemical method was compared with cultivation and it is considered that there has been little to choose between the two methods at any stage over the past 12 months. The third trial was only partially successful. In the best chemical treatment the strike of grass compared favourably with that in the conventionally established pasture alongside; but the establishment of clovers was very poor. It is considered that this was mainly due to slugs selectively eating the clover seedlings. The fourth, a crop trial, was only partially successful, but it was a start, and yielded some valuable information.

\section{Hill Country (4 Trials)}

Three of these were on low fertility virtually cloverless, steep, hill country. The first, a small scale trial sprayed on 29 September 1956 with $10 \mathrm{lb}$. of dalapon plus $8 \mathrm{lb}$. of sodium salt of PCP per acre and sown with a $32 \mathrm{lb}$. pasture mixture 10 days later, was outstandingly successful. The second trial, which was sprayed with dalapon at $5 \mathrm{lb}$. plus amitrol at $1 \mathrm{lb}$. per acre under dry pasture conditions in autumn, was a comparative failure on a dark face, but a marked success on the corresponding northerly face. In the third trial which was on a southerly face the same spray mixture was used on autumn flush pasture and an excellent kill of turf was obtained. This trial, however, was only partly successful. The bottom half of the slope established comparatively well, but the top half, apparently because it was lower in fertility, steeper, and more exposed to cold winds, was virtually a failure. The final trial, situated on a discable and fairly fertile slope, was unsuccessful in spite of a first-class kill of turf. Bird damage was the cause of failure.

A notable feature of the trials on poor hill country was the spectacular responses to spring applications of nitrogenous fertilisers. The clovers as well as the grasses responded. What is more these effects were lasting, and were plain to see the following autumn.

We see from the above summary that the results of trials were very variable. Some were excellent, some were quite good, while others were only partially successful, and there were some failures. This is however the 
kind of pattern to be expected when trying out a new method. It is from such material that we discover the principles involved.

1957-58 TRIALS

Mangahei Trial: Chemical Pasture Establishment on a Poor Virtually Cloverless Hillside

Plots were sprayed on 3 September 1957 with the following per acre rates: dalapon at $5 \mathrm{lb}$; dalapon at $5 \mathrm{lb}$. and amitrol at $1 \mathrm{lb}$.; dalapon at $2 \frac{1}{2} \mathrm{lb}$. and amitrol at $\frac{1}{2} \mathrm{lb}$.; dalapon at $5 \mathrm{lb}$. and sodium salt of PCP at $1 \mathrm{lb}$, $4 \mathrm{lb}$., and $8 \mathrm{lb}$; ; and dalapon at $2 \frac{1}{2} \mathrm{lb}$. and sodium salt of PCP at $1 \mathrm{lb}$. and $4 \mathrm{lb}$. Dalapon at $5 \mathrm{lb}$. and amitrol at $1 \mathrm{lb}$. gave the best kill with dalapon at $2 \frac{1}{2} \mathrm{lb}$. and amitrol at $\frac{1}{2} \mathrm{lb}$. next. The plots treated with sodium salt of PCP were disappointing in view of the earlier promise shown by this material.

The trial was unfortunately a failure due to birds eating the seed. A remarkable feature of the trial, however, was that the dalapon plot became virtually clover dominant as a result of the suppression of the grasses. This plot became literally packed with clovers which appeared to come from nowhere. It consisted of "native" white clover plants which had spread rapidly and individually occupied large areas of ground, while the spaces in between these white clover colonies were filled with suckling clover (Trifolium dubium).

From the aspect of suitability as a seedbed the dalapon at $5 \mathrm{lb}$. plot did not appear to be anything like as good as those where amitrol had been included. The initial kill of grasses was poorer, the moss and flat weeds were practically unaffected, while a dense population of suckling clover seedlings soon came away. Such conditions did not provide a very attractive seedbed for the sown species.

\section{Balfour Estate Trials at Pahiatua}

It was felt that the stage had been reached where more information was required on the practical application of chemical ploughing to hill country. It was also felt that it was perhaps the Department's responsibility to bridge the gap between the small plot stage and the stage where the farmer could adopt the practice with confidence. Accordingly arrangements were made to carry out a trial on a 10-acre block of hill country in which all operations including spraying, seed sowing, and the application of fertilisers and lime would be done from the air.

At the same time it was realised that future progress was equally dependent on a programme of research under hill country conditions. The following supporting trials and investigations are therefore being conducted at the same time:

(a) Time of spraying and sowing trials

(b) Study of residual effects of chemicals

(c) Seedling damage by slugs and insects

(d) Place of nitrogenous fertilisers under low fertility conditions

(e) Accuracy of aerial sowing of pasture mixtures

(f) Value of pelleting seeds

Except for the testing of accuracy of distribution of pasture mixtures all the above trials are being conducted within the 10-acre block at the Balfour Estate. The area consists essentially of a steep north-east and a steeper south-west face divided by a long narrow gully. At least threequarters of the area is too steep to be cultivated. As a previous trial had indicated that the difference in results on sunny and shady faces can be 
most marked, it was felt that this site would be very suitable for investigating the problems involved.

\section{Time of Spraying and Sowing Trials}

One of the most urgent problems requiring investigation on hill country is to determine at what time of the year spraying and sowing are likely to be most successful. The problem is complicated by the extreme differences in climate that exist between sunny and shady faces. It is probable that such differences are just as great as average differences in climate between one district and another.

Since the first chemical pasture establishment trial was laid down in Southern Hawke's Bay in autumn 1956 sprayings have been done on 28 separate occasions. The results indicate that the best kill of grasses occurs during the period from the time of full autumn pasture recovery until early spring. That is roughly from March until October or a period of about 8 months. This corresponds to the period when grass is the dominan species in the sward. There is further evidence to suggest that grass is easiest to kill when conditions immediately following spraying do not favour active growth, and therefore the recovery of the treated sward. Spraying after autumn recovery in districts where February and March are often dry months leaves little time for the sown species to establish satisfactorily before winter, especially with an early winter. Results have shown that steep shady faces can be a failure under such circumstances. The fact that the sward on low fertility country is lying in a weak open state during the late autumn-winter period gives weed seeds ample opportunity to strike and establish. Unfortunately weeds usually flourish better than pasture species under low fertility conditions.

Spraying during the late-winter early-spring period and sowing in spring in my opinion offer considerable promise; however more information on this aspect will be available when the current trials have been completed.

In the trials at the Balfour Estate spraying with dalapon at $5 \mathrm{lb}$. and dalapon at $5 \mathrm{lb}$. and amitrol at $1 \mathrm{lb}$. per acre is being done in $1 \frac{1}{2}$-chain strips directly up and down both the sunny and shady faces at about fortnightly intervals. The first spraying was done on 25 March and it is intended to continue until October. Seed is being sown across each strip at about fortnightly intervals, starting on the day of spraying. From this large number of times of spraying and sowing it is felt that some worthwhile information will emerge.

Up to the time of writing five sprayings have been made and in all cases have resulted in good sward kills. A variety of weather conditions was experienced following sprayings. After two sprayings, for instance, just on an inch of rain fell during that same night, for two other sprayings $\frac{1}{4}$ in. fell overnight and for the fifth spraying no rain fell for 48 hours afterward. It is obvious from this that good results can be obtained where moderate rain occurs shortly after spraying. This rather suggests that root absorption of dalapon and amitrol does often contribute substantially to the results obtained with extensively rooted grasses such as browntop. I can support this contention with a striking example where a much better kill of browntop was obtained where the roughage was first burnt off and then sprayed on the ash than where burning was followed by subsequently spraying the regrowth. The success of spraying on the burn can only be explained by root poisoning.

Because it is felt that lower rates of chemicals are likely to be effective over winter months, these will be tried out over this period.

Residual Effects of Chemicals

The residual effects of chemicals can at times be responsible for taking a heavy toll of seedlings. It is important therefore to know which chemicals 
are likely to have residual effects and also when such effects are likely to occur. Residual effects are minimised where there is a good sward coverage to intercept the spray, the weather immediately following spraying is fine, and the subsequent weather is fairly wet in order to flush the chemical down from the surface layers.

Because of their growth habit clovers are particularly susceptible to poisoning through the, absorption of chemicals. This is because under suitable conditions the seeds are capable of swelling to capacity within 24 hours, while the rootlets may have entered the ground within 48 hours from the time of sowing. This means that the seedling is exposed to absorption at a very early stage.

The second vulnerable feature is that clovers produce a single taproot which penetrates to a depth of 1 in. or more in the matter of a few days. Unless the chemical has been flushed out of the root zone or is at a low non-toxic concentration, the clover will be affected.

Observations on plots suggest that residual effects in clovers are related to growth rates, being greatest for subterranean, less for red clover, and least for white clover. It is probable that the reason for these differences is associated with the rate and depth of penetration of the taproot.

It would appear that where chemicals have been absorbed by the seed itself the cotyledons become bleached. Where absorption has occurred through the rootlets the cotyledons remain healthy, but the primary and/or first true leaves become bleached. Sometimes, if growing conditions are favourable, these seedlings may grow out of this condition and subsequently produce healthy leaves.

The greatest risk of residual effects is where amitrol is used in addition to dalapon. In one trial where a pasture mixture was sown immediately following spraying with dalapon at $5 \mathrm{lb}$. and amitrol at $1 \mathrm{lb}$. per acre the clover strike was extremely poor, while the ryegrass strike was noticeably reduced.

Trials in which residual effects have been studied indicate that it is risky to sow clovers, where dalapon and amitrol have been used sooner than 10 to 14 days after spraying, and then only if the equivalent of 1 to 2 in. of rain has fallen.

So far as dalapon alone is concerned residual effects have occurred where spraying and sowing have been done the same day, but only a small percentage of seedlings has been affected. Some secondary effects, affecting the first true leaves, have also occurred. A point that cannot be overlooked is that the vigour of seedlings not showing these visible symptoms could be affected.

The risk of sowing clover seed the same day as spraying where the higher rates of chemicals are used is that should rain occur soon after spraying that is sufficient to wash chemical off the leaves, but insufficient to flush the soil, absorption by the seed is almost bound to occur.

In my opinion where dalapon is used at a high rate it is better to wait a day or two if the weather is fine, or otherwise until something like 1 in. of rain has fallen.

It is possible that the extensive root system of browntop provides a large absorption mat for chemicals which could be a factor in reducing secondary residual effects. A question that comes to mind is, what happens to the absorbed chemicals after the plants die? Are they released again or are they broken down by that time?

It has been observed that neither turnips (Brassica rapa) nor Scotch thistle (Cirsium lanceolatum) seedlings appear to suffer from the residua effects of either dalapon or amitrol. Should a chemical in future be found which :. would also have a complementary effect to dalapon but would 
selectively kill many weed seedlings and not clovers and grasses, we would indeed be fortunate.

\section{Accuracy of Aerial Seed Sowing}

Preliminary tests show that a remarkably good distribution of a full pasture mixture from the air can be obtained over a swath of about $60 \mathrm{ft}$. A Piper Cub fitted with a 6-tube venturi distributor designed by Professor Weick of Texas Engineering Experimental Station was used.

Aerial Establishment of Pasture by Chemical Means at Balfour Estate

An area of 6 acres of steep hill country having a north-easterly aspect was sprayed with a Tiger Moth on 20 March last, using a mixture of 5 wh of dalapon and $1 \mathrm{lb}$. of amitrol per acre. Twenty-two gallons of water per of were applied. Allowing $40 \mathrm{ft}$. wide swaths the area was covered per acre were applied. Allowing $40 \mathrm{ft}$. wide swaths the area was covered 3 times by the aircraft. A $53 \mathrm{lb}$. pasture mixture was sown on 10 April, 21 days after spraying, using a Piper Cub with Weick's distributor. The seed was sown 2 ways and gave a very good spread. Three cwt. of molybdic superphosphate was applied by a Fletcher aircraft on the same day, while 15 cwt. of lime was applied on 25 May.

A good over-all kill of turf was obtained, but the kill was not as good as with the same amounts of chemicals applied from the ground. There was a good initial strike of both grasses and clovers.

\section{WAYS OF IMPROVING HILL COUNTRY}

There appear to be two possibilities for improving hill country by chemical means:

\section{(1) Pasture Renovation}

This applies to country which has been oversown with good clovers and topdressed and has already been brought up to a level of, say, 1 to 2 ewes per acre. Under such circumstances it would be undesirable to kill the clovers and any ryegrass (Lolium perenne) or cocksfoot (Dactylis glomerata) present. At the rate of $5 \mathrm{lb}$. of dalapon per acre, using a glomerata) present. At the rate of 5 be killed in a sward. It is probable tractor boom sprayer, browntop can be killed in a sward. It is probable there was an even distribution of clover over the paddock, a good aerial theeding of ryegrass (up to $30 \mathrm{lb}$. per acre) to establish on the dead browntop turf should be all that is necessary to complete the job. Costs browntop turf should be all that is necessary to complete the job. Costs means.

\section{(2) Pasture Renewal}

This would apply to low fertility country where no oversowing had been done. Under these circumstances a blanket kill of vegetation, including grasses, flatweeds, moss, thistles, and poor type clovers, etc., would in my opinion be the best approach. A complete kill of vegetation provides the best conditions for a maximum strike.

A chemical such as amitrol in addition to dalapon would be required for blanket killing. A complete pasture mixture would be necessary. Under low fertility conditions it is likely that the spring application of some nitrogen would be essential to turn the balance in favour of the sown species.

\section{CONCLUSION}

In conclusion, I feel that we have already come a fair way toward the goal where chemical methods on hill country will be a practical reality. However I wish to stress that chemical methods are still in the experimental stages and cannot yet be confidently recommended to farmers. 
Ill-planned attempts to establish pastures by chemical means without a proper understanding of the factors involved are more likely to set the method back than advance it

\section{DISCUSSION}

Q.-It is suggested that the trouble in applying chemicals from the air in consecutive runs is that much of the effect of the chemical is lost, due to evaporation and drift. The use of nozzles which emit large droplets, thereby lessening the effect of evaporation and drift, should be considered.

A.-In applying the spray in one run the aeroplane must cover the area accurately and a breeze could cause error. It would, perhaps, be worth while spraying from two directions at right angles to each other.

Q.-How much dalapon and amitrol are used for a blanket kill?

A. $-5 \mathrm{lb}$. of dalapon and $2 \mathrm{lb}$. of amitrol. With $2 \frac{1}{2} \mathrm{lb}$. of dalapon and $1 \mathrm{lb}$. of amitrol the sward tends to recover.

Q.-What is the yearly rainfall at Dannevirke?

A.-The area in which these trials are has a rainfall of 54 in. to $56 \mathrm{in}$. per annum. All previous trials in the Dannevirke district have been in areas which receive about 43 in. per annum. Rainfall is of little consequence as far as sward destruction is concerned, but it is very important for the subsequent establishment of oversown species. Time of spraying should be chosen to fit in with the optimum time of oversowing for the district.

Q.-Please elaborate on the effect of slugs on the establishment of pastures.

A.- Slugs are not so important on hill country as they are on land of high fertility. Only very slight control has been obtained using metaldehyde and Na PCP.

Q.-At what rates of dalapon and amitrol do clovers suffer from residual effects?

A.-No information on rates is available. Residual effect depends on weather conditions following spraying.

Q.--Is pelleted clover seed more resistant to residual effect than unpelleted seed?

A.- On information gained from two trials it appears that unpelleted seed strikes more readily than pelleted. Seed treated with potassium gibberellate established quicker and made better growth.

Comment: Too much emphasis may have been put on the residual effect of chemicals in the soil. Provided that vegetation forms a complete ground cover and fine weather follows spraying, residual effect will be slight. Trials have shown that plots may be sown on the same day of spraying, provided that a fine spray and a minimum quantity of water are used and no rain falls for a day or so. 